\title{
New Protocol to Improve the Antibacterial Activity of Platelet Rich Fibrin - In Vitro Study
}

\section{MHD Bahaa Aldin Alhaffar ( $\nabla$ bhaa.alhafar@gmail.com )}

Damascus University https://orcid.org/0000-0002-9147-189X

\section{Lama Ayoub Shibibe}

Damascus University

Chadi Soukkarieh

Damascus University

\section{Ali Abou Sulaiman \\ Damascus University}

\section{Research}

Keywords: Antibiotic, PRF, Plasma Concentrate, Biomaterial

Posted Date: November 5th, 2020

DOl: https://doi.org/10.21203/rs.3.rs-101123/v1

License: (9) This work is licensed under a Creative Commons Attribution 4.0 International License. Read Full License 


\section{Abstract}

Background: Plasma concentrate products have Rapidly developed during the last few years, and it had significantly affected regenerative medicine because of its specific features which enhance healing and reduce pain after surgeries. this research aims to create an antibiotic releasing biomaterial based on the PRF.

Methods: In-Vitro experimental study was conducted, 12 Healthy volunteers were included, each donated $(40 \mathrm{ml})$ of blood. Chukrun's protocol was used to prepare PRF $(3000 \mathrm{rpm}, 10 \mathrm{~m})$ with additional modification. Bacterial colonies and Miller-Hinton medium was prepared. Two types of bacteria were used for the culturing and incubation (Staphylococcus aureus, Enterococcus faecalis). Three Pharmaceutical forms (PF) of the antibacterial agents (Lincomycin) were incorporated with the PRF.

Results: pharmaceutical form had a significant difference on the antibacterial activity of the PRF $(P=0.000)$, ampoule and solution forms had the highest levels of bacterial growth inhibiting, however, powder failed to inhibit bacterial growth. Moreover, no significant difference was noticed between using $0.5 \mathrm{ml}$ or $1 \mathrm{ml}$ dose of antibiotic $(\mathrm{P}=339)$.

Conclusion: It is possible to incorporate antibiotic with the PRF, which will improve the antibacterial activity of PRF, creating an ARB that can be used locally adjacent to minor surgery.

\section{Background:}

Plasma concentrate products was first described in the 1970s, and it have significantly affected regenerative biomedicine (1), it can be used adjacent to surgical procedure (2), to enhance wound healing (3) and to release growth factors, which will eventually reduce the post-operative complications (4).

Platelet rich plasma (PRP) was the first generation of platelet concentrates, it combined both fibrin sealant and growth factors properties (5). However, PRP preparation had many limitations $(6,7)$, it requires a complicated method with two stage centrifuging and the use of anticoagulant (8).

Choukroun et al. in 2001 introduced the second generation of platelet concentrate, which is platelet rich fibrin (PRF) (9). The use of PRF eliminates the risk of using bovine thrombin (10) and has a very simple preparation method (9).

During the centrifugation, platelets are activated and their massive degranulation implies a very significant cytokine release, because platelet cytokines are trapped in the fibrin meshes $(11,12)$, the quantity of PDGF-BB, TGFb-1, and IGF-1 within the PRF makes it usable as a healing concentrate (12). Moreover, PRF has an antimicrobial activity against wide range of bacteria, however, this activity is limited in PRF compared to PRP or leucocyte platelet rich fibrin (L-PRF) (13).

Researchers did more advances to the centrifugation protocol creating different masses of platelet, and each product had a specific feature (14). PRF can improve wound healing and reduce the discomfort 
after surgeries (15), injectable platelet rich fibrin (I-PRF) had an effect on bone regeneration (16), (L-PRF) and advanced platelet rich fibrin (A-PRF) have a lot of application in dentistry and especially in periodontal tissue regeneration (17).

More recently, lower speeds of centrifugation are being used to create Liquid-PRF which primary composes of fibrinogen and thrombin that has 10-15 minutes before it converts to fibrin (18), and therefore, Liquid-PRF can be used as a delivery system for many types of biomolecules that can be used in regenerative medicine as Zhang proposed in 2018 (19).

Lately, attempts have been made to improve the antimicrobial activity of PRF, a recent study tested the ability of using PRF as a local antibiotic releasing device by incorporating antibiotic agent with PRF (20), Likewise, Khurshid et al added silver nanoparticles (SNP) to L-PRF to improve the antibacterial activity, and the study found that this modification improved both mechanical properties and antibacterial activity of the L-PRF (21), however, new strategies and combination approaches are still needed to develop an ideal local antibiotic delivery system (19).

Hence, developing advanced and improved forms of platelet concentrate products are still the main focus of biomedical research, in order to enhance tissue regeneration after surgeries and to reduce its complications, especially infection which remain the main complication after surgeries (22), therefore, in this research we aim to develop and introduce a protocol for production of antibiotic releasing biomaterial based on PRF scaffold.

\section{Aim Of The Research:}

1- To improve the antibacterial activity of PRF by adding antibiotic agents to its structure.

2- To study the effect of the pharmaceutical form and volume (dose) of the antibiotic agent on the PRF antibacterial activity.

3- To propose a unified protocol for the preparation of the improved PRF creating an antibiotic releasing biomaterial (ARB).

\section{Materials And Methods:}

\section{Study design:}

In-vitro experimental study was conducted in the laboratory of Biology - Faculty of Science - Damascus University - Syria.

\section{Ethical approvals:}

Ethical approvals were obtained from higher committee for medical research at Damascus University and from of scientific research committee at the faculty of Dental Medicine - Damascus university (N: 1059 
$\mathrm{t} / \mathrm{m}$ date: 15-12-2019), All methods were carried out in accordance with relevant guidelines and regulations.

Informed consent was obtained from all participants before participating in the research.

\section{Sample:}

12 Healthy volunteers were included, each donated $(40 \mathrm{ml})$ of blood, age ranged between $24-32$, research procedure and expected results were explained to each volunteer, and written consent form were collected. Each patient must have been Healthy volunteers with no systematic or blood diseases, nonsmokers, and did not take any kind of antibiotics during the last month.

\section{Research procedure:}

Different protocols have been found for the preparation of PRF, each protocol used different speed, relative $\mathrm{G}$ force and time (23). A pilot study has been conducted to test the physical properties of the PRF produced with each different protocol. Length, consistency and volume of the PRF have been assessed and the best results were noticed when using Chukrun's original protocol (24). Moreover, a small modification has been done to the original protocol which showed a significantly better results when forming ARB.

Three Pharmaceutical forms were incorporated with the fresh blood, Ampoule: Lincomycin $600 \mathrm{mg}$ $(0.5 \mathrm{ml}$, or $1.0 \mathrm{ml})$. Solution: one capsule of lincomycin $600 \mathrm{mg}$ was added to $10 \mathrm{ml}$ of saline, and two volume of solution was then added to the PRF $(0.5 \mathrm{ml}$, or $1.0 \mathrm{ml})$. Powder. lincomycin $600 \mathrm{mg}$ (capsule) was used, 100 and $50 \mathrm{mg}$ was measured using electronic scale and added to PRF.

Measurements were made on 4-time intervals: T1: after 24 hours (one day), T2: after 48 hours (two days), T3: after 120 hours (five days), T4: after 240 hours (ten days).

\section{preparation protocol:}

The final protocol was as the following:

1. $40 \mathrm{ml}$ of blood were collected from the volunteers

2. The blood samples were divided into $4(10 \mathrm{ml})$ plastic tubes without anticoagulant, plastic tubes can help to delay the PRF formation, therefore, it can be easily isolate the middle layer with the antibacterial agent from the tube in a liquid form (25). Each tube represents a group of pharmaceutical form of antibiotic (group A: ampoule form, B: powder, C: solution, D: control).

3. The tubes were immediately centrifuged at $3000 \mathrm{rpm}(400 \mathrm{~g})$, for 10 minutes. (Hettich EBA 200 Centrifuge, Germany)

4. Three layers are formed, erythrocytes concentrated in the lower part, fibrin enriched with platelets in the middle, and serum in the upper part. Immediately, the middle third from each tube was transported using a $5 \mathrm{ml}$ plastic syringe to a $5 \mathrm{ml}$ glass tube with a minimum time interval between 
each step, glass tubes can enhance the clot formation by the interaction between the silica in glass and the palates in order to create fibrin clot (26).

5. Fibrin clot is finally formed into the glass tube, and then it is ready to be cultured in the Miller-Hinton plates, no need to separate the PRF clot from the RBC layer with this protocol.

\section{Preparation of bacterial colonies:}

The bacteria used in this study (Staphylococcus aureus, Enterococcus faecalis), were isolated from Damascus pediatric hospital and incubated at $37^{\circ} \mathrm{C}$ for 24 hours. The density of the bacterial colonies was set to 0.5 MacFarland. Mueller-Hinton agar (Himedia- India) was prepared for the culturing and incubation.

Both bacteria used in this study are Gram-positive bacterium (27) (28), and can be found in healthy humans, but can also cause life-threatening infections and diseases $(29,30)$.

The antibiotic agent used in this research is Lincomycin, which is a Streptomyces Lincolnensis antibiotic (31). Lincomycin is a narrow-spectrum antibiotic with activity against Gram-positive bacteria including pathogenic types of Streptococcus, Staphylococcus and Mycoplasma (32).

Studies by Holloway et al. Have shown that strains of Staphylococcus aureus resistant to lincomycin are rare, and lincomycin is equally effective against both penicillinase and non-staphylococcus penicillinproducing, Lincomycin thus proved to be an effective drug in the treatment of staph infection (33).

\section{Measuring of bacterial growth inhibiting:}

pictures of Miller-Hinton plates were taken using digital camera (Canon 1200D, macro lens $0.25 \mathrm{~m} / 0.8 \mathrm{ft}$ ) at each time interval, Image-J software V.1.52a (Wayne Rasband, National Institutes of Health, USA) was used to measure the radius of bacterial growth inhibiting, measurement was done from the center of the sample to the edge of the bacteria inhibiting (Figure N.1).

\section{Statistical analysis:}

SPSS V.22 (statistical package for social science, IBM, 2009) was used to analysis the data. descriptive statistics was used to measure the average radius of bacterial growth inhibiting for each group, ANOVA test with post-hoc Bonferroni correction and independent samples T-test were used to test the significant difference between groups.

\section{Results:}

\section{Staphylococcus:}




\section{The effect of Pharmaceutical Form on inhibiting Staphylococcus growth in culture:}

Three forms of antibiotic agent (Lincomycin) were incorporated with the PRF, Table N.1 represent the average radius of staphylococcus growth inhibiting in culture. Ampoule form had the highest levels of bacterial growth inhibiting (T1: 29.96, T2: 32.64, T3: 32.44, T4 31.65). solution form had slightly lower result compared to ampoule $(24.78,27.55,26.63,23.44)$ retrospectively. Whereas control samples had very limited antibacterial effect and it decreased from T1 to T4 (T1: 15.19, T4: 7.40). However, powder form of antibacterial agent did not show any significant antibacterial effect $(6.51,4.14,3.38,3.05)$.

ANOVA test showed significant difference between the Pharmaceutical forms (ampoule, solution, powder and control) during the 4 times of measurement $(T 1, T 2, T 3, T 4=0.000)$ Table N.1. Post-hoc test (Bonferroni correction) was used to test the significant level between the different forms of antibiotic agent, and it is noticeable that Powder form failed to inhibit bacteria growth, and Control had the lowest effect. Table N.1

Bar chart N.1 represent the average radius of bacterial growth inhibiting between different PF. 
Table 1

- The effect of PF* on inhibiting Staph. Aureus growth.

\begin{tabular}{|c|c|c|c|c|c|c|c|}
\hline \multicolumn{2}{|c|}{$\begin{array}{l}\text { Pharmaceutical } \\
\text { form }\end{array}$} & \multirow{2}{*}{$\begin{array}{l}\text { Mean } \\
29.96\end{array}$} & \multirow{2}{*}{$\begin{array}{l}\text { ANOVA } \\
0.000\end{array}$} & \multicolumn{2}{|c|}{ Post hoc - Bonferroni test } & \multirow[b]{2}{*}{ Dep variables } & \multirow[b]{2}{*}{$P$ value } \\
\hline $\mathrm{T} 1$ & amp & & & Dep variables & $\begin{array}{l}P \\
\text { value }\end{array}$ & & \\
\hline & powder & 6.51 & & Amp - powder & 0.000 & $\begin{array}{l}\text { Powder - } \\
\text { solution }\end{array}$ & 0.000 \\
\hline & solution & 24.78 & & $\begin{array}{l}\text { Amp - } \\
\text { solution }\end{array}$ & 0.691 & Powder - control & 0.066 \\
\hline & control & 15.19 & & Amp - control & 0.000 & Solution - control & 0.033 \\
\hline \multirow[t]{4}{*}{ T2 } & amp & 32.64 & 0.000 & Dep variables & $\begin{array}{l}\mathrm{P} \\
\text { value }\end{array}$ & Dep variables & $P$ value \\
\hline & powder & 4.14 & & Amp - powder & 0.000 & $\begin{array}{l}\text { Powder - } \\
\text { solution }\end{array}$ & 0.000 \\
\hline & solution & 27.55 & & $\begin{array}{l}\text { Amp - } \\
\text { solution }\end{array}$ & 0.176 & Powder - control & 0.003 \\
\hline & control & 12.73 & & Amp - control & 0.000 & Solution - control & 0.000 \\
\hline \multirow[t]{4}{*}{ T3 } & amp & 32.44 & 0.000 & Dep variables & $\begin{array}{l}P \\
\text { value }\end{array}$ & Dep variables & $P$ value \\
\hline & powder & 3.38 & & Amp - powder & 0.000 & $\begin{array}{l}\text { Powder - } \\
\text { solution }\end{array}$ & 0.000 \\
\hline & solution & 26.63 & & $\begin{array}{l}\text { Amp - } \\
\text { solution }\end{array}$ & 0.039 & Powder - control & 0.041 \\
\hline & control & 9.14 & & Amp - control & 0.000 & Solution - control & 0.000 \\
\hline \multirow[t]{4}{*}{$\mathrm{T} 4$} & amp & 31.65 & 0.000 & Dep variables & $\begin{array}{l}\mathrm{P} \\
\text { value }\end{array}$ & Dep variables & $P$ value \\
\hline & powder & 3.05 & & Amp - powder & 0.000 & $\begin{array}{l}\text { Powder - } \\
\text { solution }\end{array}$ & 0.000 \\
\hline & solution & 23.44 & & $\begin{array}{l}\text { Amp - } \\
\text { solution }\end{array}$ & 0.007 & Powder - control & 0.400 \\
\hline & control & 7.40 & & Amp - control & 0.000 & Solution - control & 0.000 \\
\hline
\end{tabular}

The effect of the dose on inhibiting staphylococcus growth in culture:

Two doses (0.5-1 ml Amp, Sol of Lincomycin), and (50 mg, $100 \mathrm{mg}$ Lincomycin powder) were added to the PRF. Table N.2 represent the average radius of staphylococcus growth inhibiting. $0.5 \mathrm{ml}$ dose had 
higher results compared to $1 \mathrm{ml}$ dose and to control.

Moreover, independent samples T-test was used to compare between the two dose, no significant difference was noticed in ampoule group, solution form seems to be more effective in $0.5 \mathrm{ml}$ dose, with one exception in T4 $(0.5=21.38,1 \mathrm{ml}=25.5)$, and significant differences were found in T1, T4 $(0.015$, $0.000)$.

Table 2

- Effect of Dose, PF* on Staph. Aureus growth inhibiting

\begin{tabular}{|c|c|c|c|c|c|c|c|c|c|}
\hline \multicolumn{2}{|c|}{ Variables } & \multicolumn{2}{|l|}{ Dose } & \multicolumn{3}{|c|}{ Pharmaceutical form } & \multicolumn{3}{|c|}{ Independent sample T-test } \\
\hline & & average & $\begin{array}{l}\text { ANOVA } \\
\text { test }\end{array}$ & amp & powder & solution & $\begin{array}{l}\text { Amp } \\
0.5- \\
1 \mathrm{ml}\end{array}$ & $\begin{array}{l}\text { Pow } \\
0.5- \\
1 \mathrm{ml}\end{array}$ & $\begin{array}{l}\text { Solu } \\
0.5- \\
1 \mathrm{ml}\end{array}$ \\
\hline \multirow[t]{3}{*}{ T1 } & $0.5 \mathrm{ml}$ & 22.50 & \multirow[t]{3}{*}{0.339} & 30.18 & 13.03 & 26.31 & \multirow[t]{2}{*}{0.086} & \multirow[t]{2}{*}{0.058} & \multirow[t]{2}{*}{0.015} \\
\hline & $1 \mathrm{ml}$ & 18.33 & & 29.75 & .00 & 25.25 & & & \\
\hline & control & 15.19 & & . & . & . & & & \\
\hline \multirow[t]{3}{*}{$\mathrm{T} 2$} & $0.5 \mathrm{ml}$ & 23.12 & \multirow[t]{3}{*}{0.181} & 32.43 & 8.27 & 28.65 & \multirow[t]{2}{*}{0.713} & \multirow[t]{2}{*}{0.013} & \multirow[t]{2}{*}{0.822} \\
\hline & $1 \mathrm{ml}$ & 19.77 & & 32.85 & .00 & 26.45 & & & \\
\hline & control & 12.73 & & & . & . & & & \\
\hline \multirow[t]{3}{*}{ T3 } & $0.5 \mathrm{ml}$ & 22.54 & \multirow[t]{3}{*}{0.060} & 32.13 & 6.75 & 28.75 & \multirow[t]{2}{*}{0.459} & \multirow[t]{2}{*}{0.008} & \multirow[t]{2}{*}{0.103} \\
\hline & $1 \mathrm{ml}$ & 19.08 & & 32.75 & .00 & 24.50 & & & \\
\hline & control & 9.14 & & . & . & . & & & \\
\hline \multirow[t]{3}{*}{ T4 } & $0.5 \mathrm{ml}$ & 19.58 & \multirow[t]{3}{*}{0.061} & 31.25 & 6.10 & 21.38 & \multirow[t]{2}{*}{0.268} & \multirow[t]{2}{*}{0.013} & \multirow[t]{2}{*}{$<0.001$} \\
\hline & $1 \mathrm{ml}$ & 19.18 & & 32.05 & .00 & 25.50 & & & \\
\hline & control & 7.40 & & . & . & . & & & \\
\hline
\end{tabular}

\section{Enterococcus:}

\section{The effect of Pharmaceutical form on inhibiting Enterococcus growth in culture:}

Two forms only (ampoule, solution) of antibacterial agents (Lincomycin) were incorporated with the PRF to test the effectiveness of the new PRF on inhibiting Enterococcus growth in culture (powder was excluded because it has failed to give significant results when it was tested on Staphylococcus). 
Table N.3 represent the average radius of Enterococcus growth inhibiting, Ampoule form had the highest level of antibacterial effect during the four times of measurement (T1: 24.92, T2: $22.88, T 3=20.55, \mathrm{~T} 4=$ 4.5). Solution antibacterial effect decreased rapidly between $T 1$ and $T 4(22.78,3.33)$ retrospectively. Control samples showed very limited antibacterial effect on Enterococcus during T1, T2 $(12.70,4.72)$ and completely lost its effectiveness in T3, T4. Bar chart N.2

ANOVA test showed significant difference in $\mathrm{T} 1, \mathrm{~T} 2, \mathrm{~T} 3$, but there was no significant difference in $\mathrm{T} 4$ (0.604). Post hoc test (Bonferroni correction) was used to detect the difference within each two variables (amp, sol, con):

Table 3

- The effect of PF* on inhibiting E. faecalis growth.

\begin{tabular}{|c|c|c|c|c|c|}
\hline \multicolumn{2}{|c|}{ Pharmaceutical form } & \multirow[t]{2}{*}{ Mean } & \multirow[t]{2}{*}{ ANOVA } & \multicolumn{2}{|c|}{ Post hoc - Bonferroni test } \\
\hline & & & & Dep - variables & $P$-value \\
\hline \multirow[t]{3}{*}{$\mathrm{T} 1$} & amp & 24.92 & \multirow[t]{3}{*}{0.000} & Amp-sol & 0.069 \\
\hline & solution & 20.78 & & Amp-con & 0.000 \\
\hline & control & 12.70 & & Sol- con & 0.001 \\
\hline \multirow[t]{3}{*}{ T2 } & amp & 22.88 & \multirow[t]{3}{*}{0.000} & Amp-sol & 0.003 \\
\hline & solution & 13.35 & & Amp-con & 0.000 \\
\hline & control & 4.72 & & Sol- con & 0.006 \\
\hline \multirow[t]{3}{*}{ T3 } & amp & 20.55 & \multirow[t]{3}{*}{0.000} & Amp-sol & 0.020 \\
\hline & solution & 10.88 & & Amp-con & 0.000 \\
\hline & control & .00 & & Sol- con & 0.009 \\
\hline \multirow[t]{3}{*}{$\mathrm{T} 4$} & amp & 4.50 & \multirow[t]{3}{*}{0.604} & Amp-sol & 1.000 \\
\hline & solution & 3.33 & & Amp- con & 1.000 \\
\hline & control & 0.00 & & Sol- con & 1.000 \\
\hline * $\mathrm{P}$ & Iarmaceutical & rm. & & & \\
\hline
\end{tabular}

The effect of the added dose on inhibiting Enterococcus growth in culture

Two doses of antibiotics $(0.5 \mathrm{ml}, 1 \mathrm{ml})$ were used to test the effectiveness of the ARB on inhibiting Enterococcus growth. Very similar results were noticed between 0.5 and $1 \mathrm{ml}$ in the four times of measurements (table N.4). 
ANOVA and post hoc test results are represented in (Table N.4). No significant differences were noticed between $0.5-1 \mathrm{ml}$ dose of the ampoule form.

Table 4

- effect of Dose, PF* on Enterococcus growth inhibiting

\begin{tabular}{|c|c|c|c|c|c|c|c|c|c|}
\hline \multicolumn{2}{|c|}{ Variables } & \multicolumn{4}{|l|}{ Dose } & \multicolumn{2}{|c|}{$\begin{array}{l}\text { Pharmaceutical } \\
\text { form }\end{array}$} & \multicolumn{2}{|c|}{$\begin{array}{l}\text { Independent } \\
\text { sample T-test }\end{array}$} \\
\hline & & \multirow{2}{*}{$\begin{array}{l}\text { Average } \\
22.82\end{array}$} & \multirow{2}{*}{$\begin{array}{l}\begin{array}{l}\text { ANOVA } \\
\text { test }\end{array} \\
0.000\end{array}$} & \multicolumn{2}{|c|}{ Post hoc test } & \multirow{2}{*}{$\begin{array}{l}\text { Ampoule } \\
24.23\end{array}$} & \multirow{2}{*}{$\begin{array}{l}\text { Solution } \\
21.40\end{array}$} & \multirow{2}{*}{$\begin{array}{l}\text { Amp } \\
0.5- \\
1 \mathrm{ml} \\
0.086\end{array}$} & \multirow{2}{*}{$\begin{array}{l}\text { Sol } \\
0.5- \\
1 \mathrm{ml} \\
0.523\end{array}$} \\
\hline $\mathrm{T} 1$ & $0.5 \mathrm{ml}$ & & & $\begin{array}{l}0.5- \\
1 \mathrm{~mL}\end{array}$ & 1.000 & & & & \\
\hline & $1 \mathrm{ml}$ & 22.88 & & $\begin{array}{l}0.5 \mathrm{ml}- \\
\text { con }\end{array}$ & 0.000 & 25.60 & 20.17 & & \\
\hline & control & 12.70 & & $\begin{array}{l}1 \mathrm{ml}- \\
\text { con }\end{array}$ & 0.000 & . & . & & \\
\hline \multirow[t]{3}{*}{ T2 } & $0.5 \mathrm{ml}$ & 18.27 & 0.001 & $\begin{array}{l}0.5- \\
1 \mathrm{~mL}\end{array}$ & 1.000 & 24.07 & 12.47 & 0.408 & .992 \\
\hline & $1 \mathrm{ml}$ & 17.97 & & $\begin{array}{l}0.5 \mathrm{ml}- \\
\text { con }\end{array}$ & 0.003 & 21.70 & 14.23 & & \\
\hline & control & 4.72 & & $\begin{array}{l}1 \mathrm{ml}- \\
\text { con }\end{array}$ & 0.004 & . & . & & \\
\hline \multirow[t]{3}{*}{ T3 } & $0.5 \mathrm{ml}$ & 16.25 & 0.001 & $\begin{array}{l}0.5- \\
1 \mathrm{~mL}\end{array}$ & 1.000 & 23.97 & 8.53 & 0.786 & 0.699 \\
\hline & $1 \mathrm{ml}$ & 15.18 & & $\begin{array}{l}0.5 \mathrm{ml}- \\
\text { con }\end{array}$ & 0.003 & 17.13 & 13.23 & & \\
\hline & control & .00 & & $\begin{array}{l}1 \mathrm{ml}- \\
\mathrm{con}\end{array}$ & 0.005 & . & . & & \\
\hline \multirow[t]{3}{*}{$\mathrm{T} 4$} & $0.5 \mathrm{ml}$ & 4.50 & 0.604 & $\begin{array}{l}0.5- \\
1 \mathrm{~mL}\end{array}$ & 1.000 & 9.00 & .00 & 0.016 & 0.016 \\
\hline & $1 \mathrm{ml}$ & 3.33 & & $\begin{array}{l}0.5 \mathrm{ml}- \\
\text { con }\end{array}$ & 1.000 & .00 & 6.67 & & \\
\hline & control & .00 & & $\begin{array}{l}1 \mathrm{ml}- \\
\mathrm{con}\end{array}$ & 1.000 & & . & & \\
\hline
\end{tabular}

\section{Discussion:}

Clinicians have been using PRF and other platelet concentration products with the regenerative procedure in order to enhance the healing and to reduce the postoperative complications (34), however, studies have 
shown that PRF have only mild antibacterial activity against some bacterial agents like $S$. aureus, and it is not affective against resistance bacteria like $F . \operatorname{Nucleatum}(35,36)$. Moreover, the most frequent postoperative complication in minor surgery is infection due to the exposure of the flap (or membrane) and the bacterial colonization of the wound $(22,37)$.

Therefore, this research aimed to improve the antibacterial activity of PRF by adding different forms of antibiotics and developing a protocol for the preparation of antibiotic releasing biomaterial (ARB) based on platelet rich fibrin (PRF), which will help to overcome the infection after minor surgery procedure.

Local ARB can be effective where infection is predictable, and can reduce the use of antibiotic especially in the field of dental surgeries (38), and also, eliminating the side effect of using systematic antibiotic (cell toxicity, and antibiotic resistance) (39).

Several studies tried to improve the PRF, one study added silver nanoparticles (SNP) which created SNP modified PRF, and this study concluded that SNP modified PRF had an improved mechanical properties and higher antimicrobial activity (21), other study evaluated release kinetics of different antibiotic from PRF, the results showed that PRF could release antibiotics for a week (40).

The two bacteria chosen in this research are $S$. aureus, and E. faecalis because of their well-known roll to cause infection $(41,42)$, also, they are a major cause of hospital wound infection (43), both bacteria were isolated from pediatric blood infection from Damascus children Hospital.

Three forms of antibiotic agent were used in this research, and the research showed that adding ampoule or solution form can significantly increase the antibiotic activity of PRF, compared with normal PRF (control), and ARB could release antibiotic for 10 days. on the other hand, powder form failed to improve PRF, this might be because antibiotic in powder form changed the osmotic pressure of the blood resulting in cells desolation. No significant difference between ampoule and solution form was noticed, however, ampoule had higher results, this can be explained because ampoule is already prepared for IV, IM injection while the solution concentration may have been diluted in the serum. No previous study had studied the effect of pharmaceutical form on the antibiotic release of PRF.

$0.5 \mathrm{ml}$ and $1 \mathrm{ml}$ volume had similar results, however, $0.5 \mathrm{ml}$ had a slightly higher antibacterial activity, this result agrees with other study, because in the protocol used in the previous research, PRF has failed to form in $1 \mathrm{ml}$ volume samples (20).

The antibiotic release in our study lasted for 10 days, other study recorded that the bacterial growth inhabitation lasted between $4-7$ days $(20,40)$.

The concept of antibiotic releasing biomaterial (ARB) introduced in this research might have an important future clinical relevance with general practice, because infection of the surgical site remain the main complication after minor surgery (22). The use of ARB can have an important role in reducing infection which interfere with second intention healing after dermatologic surgery $(44,45)$ or after open fracture 
(46), and will be of great interest in oral surgeries and treating of periodontal diseases and overall eliminating surgical site infection by gradual local releasing of antibiotic (47).

We recommend further research of the protocol proposed in this study using different antibiotic agents and bacteria in order to prepare this concept for the clinical application.

\section{Conclusion:}

Within the limits of this study, it can concluded that the proposed protocol in this study has succeeded to improve the antibacterial properties of PRF, creating an antibiotic releasing biomaterial (ARB) that can be used widely after minor surgery, where infection is very predictable and highly affect the survival rate of the surgery. The use of ARB can significantly reduce the use of systematic antibiotics which will directly reduce the complications of using systematic antibiotics, and indirectly affect the worldwide antibiotic resistance crisis. More clinical and animal research is required to verify the healing and antimicrobial properties of the ARB.

\section{Declarations}

\section{Ethics approval and consent to participate:}

The research ethical approval reference number is 135\S - data: 15-12-2019, and it was obtained from the scientific committee at the faculty of dental medicine, and the ethical committee at Damascus university

\section{Consent for publication}

Not applicable.

\section{Availability of data and material}

All necessary data are presented within the manuscript. All other materials and data are available upon request. For any more details regarding the data of this research please contact the corresponded author.

\section{Competing interests}

The authors declared no potential conflicts of interest with respect to the research, authorship and/or publication of this article.

\section{Funding}

The authors confirm the independence of this research completely from any governmental or nongovernmental authorities or local /international organizations, and the research is self-funded by the authors.

\section{Authors' contributions}


A.B: developed the idea, designed the research, wrote the manuscript, analyzed the data, finalized the manuscript.

S.L: Bacterial isolation and culture, data collection, helped writing the manuscript.

S.C: helped with laboratory procedure, reviewed the article.

S.A.A: reviewed the article, helped finalizing the manuscript.

\section{References}

1. Prakash S, Thakur A. Platelet concentrates: past, present and future. J Maxillofac Oral Surg. 2011;10(1):45-9.

2. Dohan Ehrenfest DM, Andia I, Zumstein MA, Zhang CQ, Pinto NR, Bielecki T. Classification of platelet concentrates (Platelet-Rich Plasma-PRP, Platelet-Rich Fibrin-PRF) for topical and infiltrative use in orthopedic and sports medicine: current consensus, clinical implications and perspectives. Muscles Ligaments Tendons J. 2014;4(1):3-9.

3. Polimeni G, Xiropaidis AV, Wikesjo UM. Biology and principles of periodontal wound healing/regeneration. Periodontol 2000. 2006;41:30-47.

4. Shah R, M GT, Thomas R, Mehta DS. An Update on the Protocols and Biologic Actions of Platelet Rich Fibrin in Dentistry. Eur J Prosthodont Restor Dent. 2017;25(2):64-72.

5. Borzini P, Mazzucco L. Platelet gels and releasates. Curr Opin Hematol. 2005;12(6):473-9.

6. Valenti Azcarate A, Lamo-Espinosa J, Aquerreta Beola JD, Hernandez Gonzalez M, Mora Gasque G, Valenti Nin JR. Comparison between two different platelet-rich plasma preparations and control applied during anterior cruciate ligament reconstruction. Is there any evidence to support their use? Injury. 2014;45(Suppl 4):36-41.

7. Marx RE. Platelet-rich plasma: evidence to support its use. J Oral Maxillofac Surg. 2004;62(4):48996.

8. Badran Z, Abdallah MN, Torres J, Tamimi F. Platelet concentrates for bone regeneration: Current evidence and future challenges. Platelets. 2018;29(2):105-12.

9. Dohan DM, Choukroun J, Diss A, Dohan SL, Dohan AJ, Mouhyi J, et al. Platelet-rich fibrin (PRF): a second-generation platelet concentrate. Part I: technological concepts and evolution. Oral Surg Oral Med Oral Pathol Oral Radiol Endod. 2006;101(3):e37-44.

10. Sunitha Raja V, Munirathnam Naidu E. Platelet-rich fibrin: evolution of a second-generation platelet concentrate. Indian journal of dental research: official publication of Indian Society for Dental Research. 2008;19(1):42-6.

11. Mosesson MW, Siebenlist KR, Meh DA. The structure and biological features of fibrinogen and fibrin. Ann N Y Acad Sci. 2001;936:11-30. 
12. Dohan DM, Choukroun J, Diss A, Dohan SL, Dohan AJ, Mouhyi J, et al. Platelet-rich fibrin (PRF): a second-generation platelet concentrate. Part II: platelet-related biologic features. Oral Surg Oral Med Oral Pathol Oral Radiol Endod. 2006;101(3):e45-50.

13. Kour P, Pudakalkatti PS, Vas AM, Das S, Padmanabhan S. Comparative Evaluation of Antimicrobial Efficacy of Platelet-rich Plasma, Platelet-rich Fibrin, and Injectable Platelet-rich Fibrin on the Standard Strains of Porphyromonas gingivalis and Aggregatibacter actinomycetemcomitans. Contemp Clin Dent. 2018;9(Suppl 2):325-s30.

14. Zrnc TA, Metzler P, Zemann W, Ghanaati S. PRF in dentistry - a short synopsis about implementation and workflow. Swiss Dent J. 2018;128(9):712-3.

15. Lektemur Alpan A, Torumtay Cin G. PRF improves wound healing and postoperative discomfort after harvesting subepithelial connective tissue graft from palate: a randomized controlled trial. Clin Oral Investig. 2020;24(1):425-36.

16. Xie H, Xie YF, Liu Q, Shang LY, Chen MZ. [Bone regeneration effect of injectable-platelet rich fibrin (IPRF) in lateral sinus lift: a pilot study]. Shanghai Kou Qiang Yi Xue. 2019;28(1):71-5.

17. Pitzurra L, Jansen IDC, de Vries TJ, Hoogenkamp MA, Loos BG. Effects of L-PRF and A-PRF + on periodontal fibroblasts in in vitro wound healing experiments. J Periodontal Res. 2019.

18. Fujioka-Kobayashi M, Miron RJ, Hernandez M, Kandalam U, Zhang Y, Choukroun J. Optimized Platelet-Rich Fibrin With the Low-Speed Concept: Growth Factor Release, Biocompatibility, and Cellular Response. J Periodontol. 2017;88(1):112-21.

19. Miron RJ, Zhang Y. Autologous liquid platelet rich fibrin: A novel drug delivery system. Acta Biomater. 2018;75:35-51.

20. Polak D, Clemer-Shamai N, Shapira L. Incorporating antibiotics into platelet-rich fibrin: A novel antibiotics slow-release biological device. J Clin Periodontol. 2019;46(2):241-7.

21. Khorshidi H, Haddadi P, Raoofi S, Badiee P, Dehghani Nazhvani A. Does Adding Silver Nanoparticles to Leukocyte- and Platelet-Rich Fibrin Improve Its Properties? Biomed Res Int. 2018;2018:8515829.

22. Heal C, Buettner P, Browning S. Risk factors for wound infection after minor surgery in general practice. Med J Aust. 2006;185(5):255-8.

23. Sevchenko SRM, Bonkovsky 0. Technologies for producing platelet masses for regenerative medicine. Науковий вісник ветеринарної медицини. 2019;№ 2. (С.):105 - 17.

24. Choukroun J, Diss A, Simonpieri A, Girard MO, Schoeffler C, Dohan SL, et al. Platelet-rich fibrin (PRF): a second-generation platelet concentrate. Part V: histologic evaluations of PRF effects on bone allograft maturation in sinus lift. Oral Surg Oral Med Oral Pathol Oral Radiol Endod. 2006;101(3):299-303.

25. Zeiler T, Kretschmer VV. Platelet Concentrates from Automated Apheresis - Past, Present and Future Developments. Infusionsther Transfusionsmed. 2000;27(3):119-26.

26. BAINS GUPTAV, SINGH VK, MATHUR G, A. \& BAINS R. Regenerative potential of platelet rich fibrin in dentistry: literature review. Asian Journal of Oral Health Allied Sciences. 2011;1:23-8. 
27. Smith AJ, JMS, Bagg J. The ecology of Staphylococcus species in the oral cavity. J Med Microbiol. 2001;50(11):940-6.

28. Ryan KJRC, editor. Sherris Medical Microbiology (4th ed.). McGraw Hill 2004:294-5.

29. Kim GY, Lee CH. Antimicrobial susceptibility and pathogenic genes of Staphylococcus aureus isolated from the oral cavity of patients with periodontitis. J Periodontal Implant Sci. 2015;45(6):223-8.

30. Wang QQ, Zhang CF, Chu CH, Zhu XF. Prevalence of Enterococcus faecalis in saliva and filled root canals of teeth associated with apical periodontitis. Int J Oral Sci. 2012;4(1):19-23.

31. D MJ, A., and DeBoer C. Linconqcin, a New Antibiotic, I. Discovery and Biological Properties, Antimicrob. Agents Chemother. 1962;2:554-9.

32. Birkenmeyer RDK. Lincomycin. XI. Synthesis and structure of clindamycin, a potent antibacterial agent. J Med Chem. 1970;13(4):616-9.

33. Holloway WJ. The therapeutic potential of the lincomycin antibiotics. Int Z Klin Pharmakol Ther Toxikol. 1971;4(3):321-4.

34. Castro AB, Meschi N, Temmerman A, Pinto N, Lambrechts P, Teughels W, et al. Regenerative potential of leucocyte- and platelet-rich fibrin. Part A: intra-bony defects, furcation defects and periodontal plastic surgery. A systematic review and meta-analysis. J Clin Periodontol. 2017;44(1):67-82.

35. Bielecki TM, Gazdzik TS, Arendt J, Szczepanski T, Krol W, Wielkoszynski T. Antibacterial effect of autologous platelet gel enriched with growth factors and other active substances: an in vitro study. $J$ Bone Joint Surg Br. 2007;89(3):417-20.

36. Moojen DJ, Everts PA, Schure RM, Overdevest EP, van Zundert A, Knape JT, et al. Antimicrobial activity of platelet-leukocyte gel against Staphylococcus aureus. J Orthop Res. 2008;26(3):404-10.

37. Zhang J, Xu Q, Huang C, Mo A, Li J, Zuo Y. Biological properties of an anti-bacterial membrane for guided bone regeneration: an experimental study in rats. Clin Oral Implants Res. 2010;21(3):321-7.

38. McLaren AC. Alternative materials to acrylic bone cement for delivery of depot antibiotics in orthopaedic infections. Clin Orthop Relat Res. 2004(427):101-6.

39. Verdel BM, van Puijenbroek EP, Souverein PC, Leufkens HG, Egberts AC. Drug-related nephrotoxic and ototoxic reactions: a link through a predictive mechanistic commonality. Drug Saf. 2008;31(10):87784.

40. Knafl D, Thalhammer F, Vossen MG. In-vitro release pharmacokinetics of amikacin, teicoplanin and polyhexanide in a platelet rich fibrin-layer (PRF)-a laboratory evaluation of a modern, autologous wound treatment. PLoS One. 2017;12(7):e0181090.

41. Smith AJ, Jackson MS, Bagg J. The ecology of Staphylococcus species in the oral cavity. J Med Microbiol. 2001;50(11):940-6.

42. Molander A, Reit C, Dahlen G, Kvist T. Microbiological status of root-filled teeth with apical periodontitis. Int Endod J. 1998;31(1):1-7. 
43. Rajkumari N, Mathur P, Misra MC. Soft Tissue and Wound Infections Due to Enterococcus spp. Among Hospitalized Trauma Patients in a Developing Country. J Glob Infect Dis. 2014;6(4):189-93.

44. Schimmel J, Belcher M, Vieira C, Lawrence N, Decker A. Incidence of Surgical Site Infections in Second Intention Healing After Dermatologic Surgery. Dermatol Surg. 2020.

45. Soon SL. Commentary on Incidence of Surgical Site Infections in Second Intention Healing After Dermatologic Surgery. Dermatol Surg. 2020.

46. Prada C, Tanner SL, Marcano-Fernandez FA, Bzovsky S, Schemitsch EH, Jeray K, et al. How Successful Is Antibiotic Treatment for Superficial Surgical Site Infections After Open Fracture? A Fluid Lavage of Open Wounds (FLOW) Cohort Secondary Analysis. Clin Orthop Relat Res. 2020.

47. Chen AF, Brown GA. Management of Surgical Site Infections. J Am Acad Orthop Surg. 2020;28(6):e238-e41.

\section{Figures}

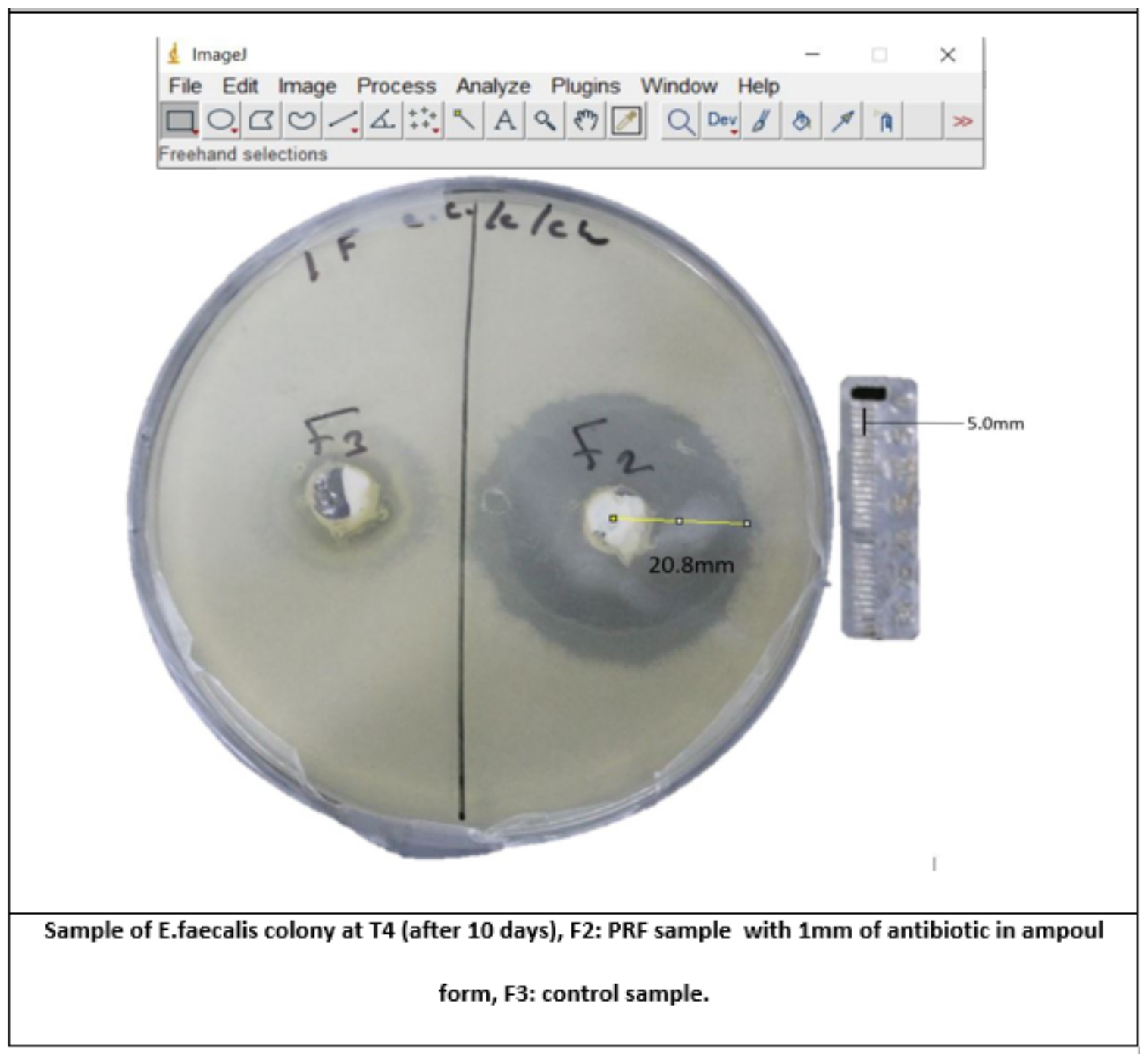

\section{Figure 1}


measuring the radius of bacterial growth inhibiting using Image-J

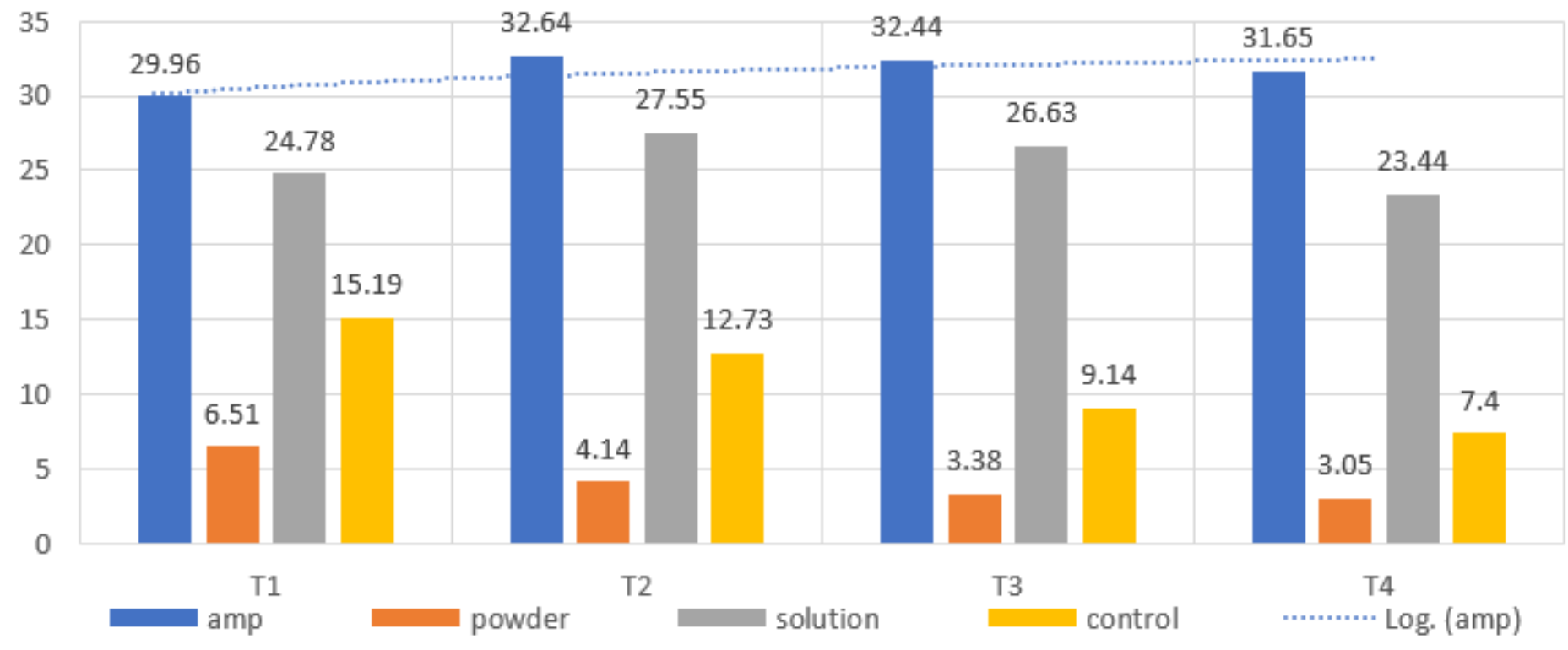

*PF: pharmaceutical form.

\section{Figure 2}

The effect of PF* on inhibiting Staphylococcus growth in culture 30

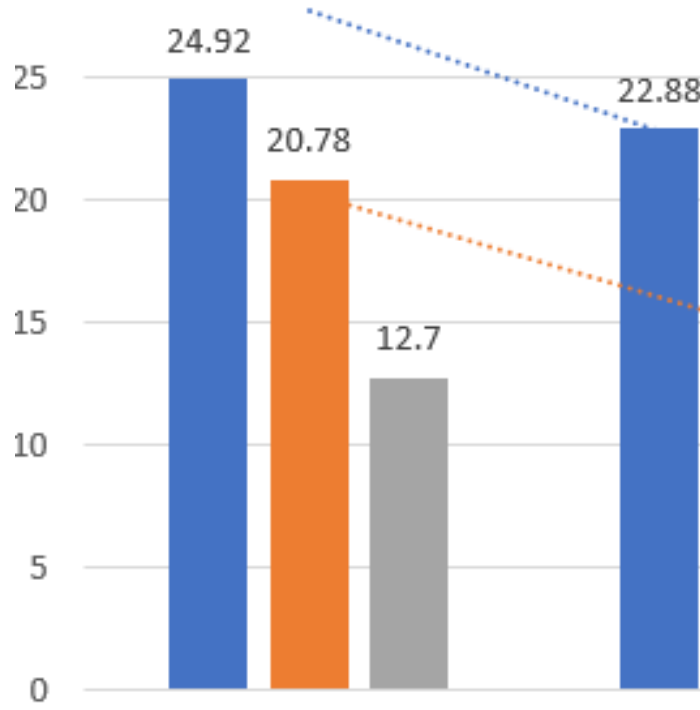

T1

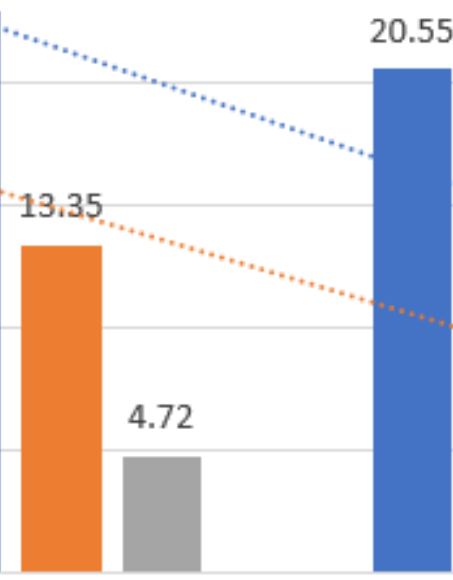

T2

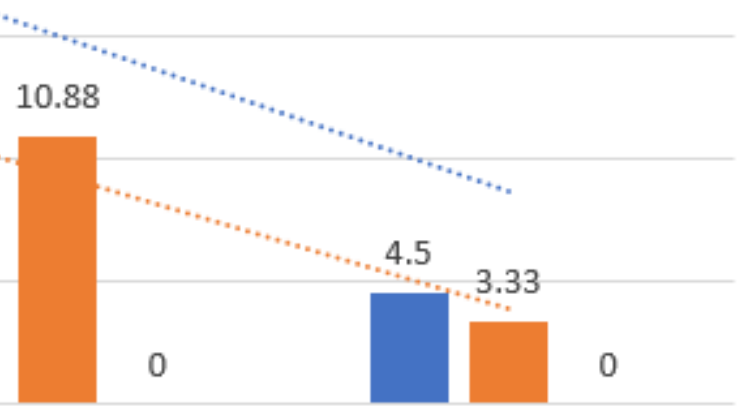

T3

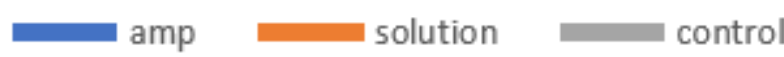

Linear (amp) Linear (solution)

\section{Figure 3}

The effect of PF on inhibiting Enterococcus growth in culture 